\title{
Understanding the mechanism of Pd-catalyzed allylic substitution of the cyclic difluorinated carbonates
}

\author{
Jun $\mathrm{Xu}^{1}$, Xiao-Long Qiu ${ }^{1}$ and Feng-Ling Qing ${ }^{* 1,2}$
}

\section{Full Research Paper}

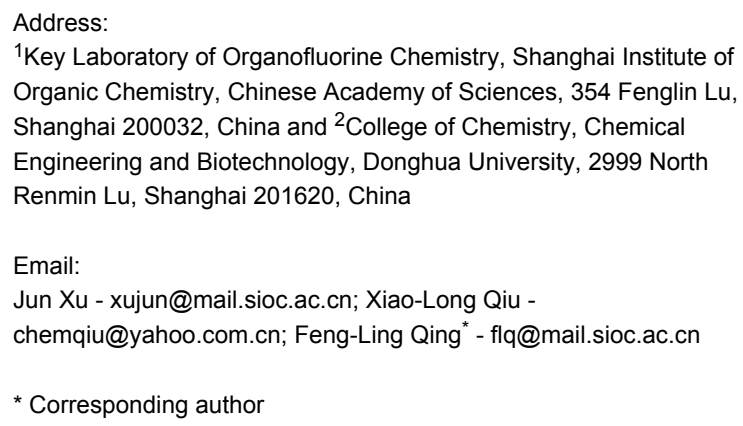

${ }^{1}$ Key Laboratory of Organofluorine Chemistry, Shanghai Institute of Organic Chemistry, Chinese Academy of Sciences, 354 Fenglin Lu, Shanghai 200032, China and ${ }^{2}$ College of Chemistry, Chemical Engineering and Biotechnology, Donghua University, 2999 North Renmin Lu, Shanghai 201620, China

Email:

Jun Xu - xujun@mail.sioc.ac.cn; Xiao-Long Qiu -

chemqiu@yahoo.com.cn; Feng-Ling Qing ${ }^{*}$ - flq@mail.sioc.ac.cn

* Corresponding author

Open Access

Beilstein Journal of Organic Chemistry 2008, 4, No. 18

doi:10.3762/bjoc.4.18

Received: 18 January 2008

Accepted: 15 May 2008

Published: 27 May 2008

(c) 2008 Xu et al; licensee Beilstein-Institut.

License and terms: see end of document.

\begin{abstract}
We present a mechanistic investigation of Pd-catalyzed allylic substitution of cyclic gem-difluorinated carbonates $\mathbf{1}$ and $\mathbf{4}$, previously employed in the synthesis of 3', 3'-difluoro-2'-hydroxymethyl-4',5'-unsaturated carbocyclic nucleosides in 17 steps. The substitution features a reversal of regioselectivity caused by fluorine.
\end{abstract}

\section{Background}

Carbocyclic nucleosides (CNAs), in which the furanose oxygen atoms of the 4'-oxonucleosides are substituted by $\mathrm{CH}_{2}$, have received considerable attention because they exhibit greater metabolic stability toward nucleoside phosphorylases and higher lipophilicity, two properties that are potentially beneficial in terms of increased in vivo half life, oral efficiency and cell wall penetration [1,2]. Based on CNA skeletons, 1,2-disubstituted carbocyclic nucleosides (OTCs) recently attracted more and more attention [3-9], especially after De Clercq et al. found that some OTCs showed moderate to good activity against murine leukemia cells L1210/0, human T-lymphocyte cells Molt4/C8, and CEM/0 via topological substructural approach to molecular design (TOSS-MODE) [10]. As part of our ongoing and continual efforts to prepare potential bioactive fluorinated nucleosides, our group recently described the stereoselective synthesis of 3',3'-difluoro-4',5'-unsaturated OTCs $\mathbf{2}-\mathbf{3}$ and $\mathbf{5}$ [11]. The whole synthesis highlighted the stereoselective Reformatskii-Claisen rearrangement, ring-closing metathesis (RCM), and Pd-catalyzed allylic substitution, in which the regioselectivity was reversed from that of nonfluorinated substrates. This reversed regioselectivity caused by fluorine interests us greatly. Herein, we present a mechanistic investigation of Pd-catalyzed allylic substitution of cyclic gem-difluorinated carbonates.

\section{Results and Discussion}

On installation of pyrimidine bases into the gem-difluorinated allylic carbonates 1 and 4, our group found that the $\gamma$-substitution products $\mathbf{2}, \mathbf{3}$ and $\mathbf{5}$ were surprisingly generated exclusively in good yields, respectively, when the compounds $\mathbf{1}$ and $\mathbf{4}$ 
reacted with suitably protected nucleobases 3-benzoyluracil and 3-benzoylthymine in the presence of a catalytic amount of $\mathrm{Pd}\left(\mathrm{PPh}_{3}\right)_{4}$ at $60{ }^{\circ} \mathrm{C}$ in THF (Scheme 1) [11]. The exclusive regioselectivities of $\mathrm{Pd}$-catalyzed allylic alkylation (Pd-AA) reactions were very interesting. Although Konno et al. have reported that the electron-withdrawing fluoroalkyl groups would alter the regioselectivities of acyclic allylic alkylation compared with their non-fluorinated counterparts [12-17], their reactions mostly concerned the Pd-catalyzed regio- and stereoselective formate reduction of fluorine-containing allylic mesylates. To the best of our knowledge, the effect of gemdifluoromethylene group on Pd-catalyzed cyclic allylic substitution has never been addressed so far. The regioselectivity was totally different from those of nonfluorinated substrates [18].

Unexpected and specific regioselectivity of Pd-catalytic asymmetric reactions of the gem-difluorinated allylic intermediates 1 and $\mathbf{4}$ prompted us to investigate further the mechanism of these reactions. Currently, one of the most direct tactics for mechanistic investigation of Pd-AA reaction was built on the analysis of crystal structure and ${ }^{13} \mathrm{C}$ NMR spectroscopy of Pd- $\pi$-allyl complex $[19,20]$. The orientation of attack of nucleophiles on the Pd- $\pi$-allyl complex could be illustrated via examining the ${ }^{13} \mathrm{C}$ NMR chemical shifts of three carbon atoms attached to the palladium. According to the model of DeShong et al. [21], it was anticipated that a symmetrical Pd- $\pi$-allyl complex should be temporarily generated once the compounds $\mathbf{1}$ or $\mathbf{4}$ were treated with palladium catalyst. Thus, $\alpha$-substitution products should be afforded considering the steric effects. However, only $\gamma$-substitution products $\mathbf{2}-\mathbf{3}$ and $\mathbf{5}$ were isolated in our case, which, in our opinion, resulted from the specific electron-withdrawing property of the gem-difluoromethylene group. To further validate our hypothesis and the proposed model of
DeShong et al., we decided to explore the crystal structure and ${ }^{13} \mathrm{C}$ NMR of the corresponding Pd- $\pi$-allyl complex.

In 2000, Bäckvall and co-workers investigated the X-ray structures for cis and trans isomers of [(1,2,3- $\eta)$-4-acetoxycyclohex2-enyl]palladium chloride dimers [22]. They found that the $\mathrm{X}$-ray structure of trans-trans dimer displayed asymmetric allyl-palladium bonding where the $\mathrm{Pd}-\mathrm{C} 3$ bond was shorter than the $\mathrm{Pd}-\mathrm{C} 1$ bond. Their study provided the first direct evidence for the presence of electronic interaction in the Pd-catalytic asymmetric allylic reactions of 1-acetoxy-4-chloro-2-cyclohexene. Based on their study, we first converted the precursor compound 6 to the $\gamma$-chloro-subsituted compound 7 in $78 \%$ yield by treatment with NCS $/ \mathrm{PPh}_{3}$ in THF at $0{ }^{\circ} \mathrm{C}$ (Scheme 2). Using the stereodivergent method of Kurosawa et al. [23], trans-trans dimer 8 and cis-cis dimer 9 were prepared in 74\% and $86 \%$ yield by treatment of the chloride 7 with $\operatorname{Pd}(\mathrm{dba})_{2}$ using toluene and DMSO as the solvent, respectively.

To our delight, the crystal of trans-trans dimer 8 was suitable for X-ray analysis (Figure 1). It was clear that 1,2bis(benzyloxy)ethyl moieties in dimer 8 occupied the positions trans to the corresponding palladium atoms. Also obvious was that allyl-palladium bonding in trans-trans dimer $\mathbf{8}$ was almost symmetric: within experimental error, there was not much difference between the Pd1-C2 bond length $2.105 \AA$ (11) and Pd1-C4 bond length $2.118 \AA$ (9), and between the Pd1-C4-C3 bond angle $68.9^{\circ}(6)$ and $\mathrm{Pd} 1-\mathrm{C} 2-\mathrm{C} 3$ bond angle $69.2^{\circ}$ (7) (Table 1). Thus, as expected from the proposed model [21], the symmetrical Pd- $\pi$-allyl complex was generated. According to the X-ray structure of the trans-trans dimer $\mathbf{8}$, it was clear that $\mathrm{C} 4$ position was more shielded than the $\mathrm{C} 2$ position, which should guide the attack of nucleophiles from the $\mathrm{C} 2$ position.

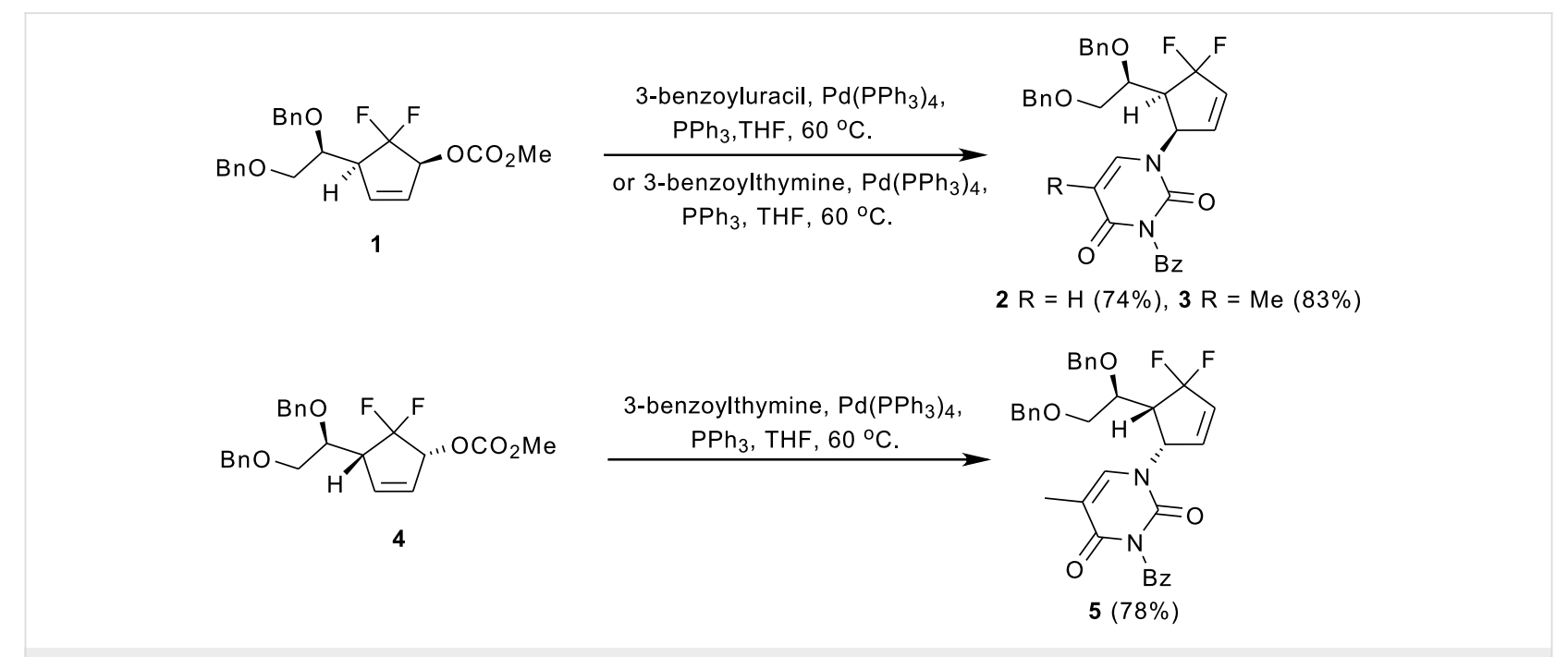

Scheme 1: Pd-catalyzed allylic substitution of the gem-difluorinated allylic carbonates 1 and 4 . 


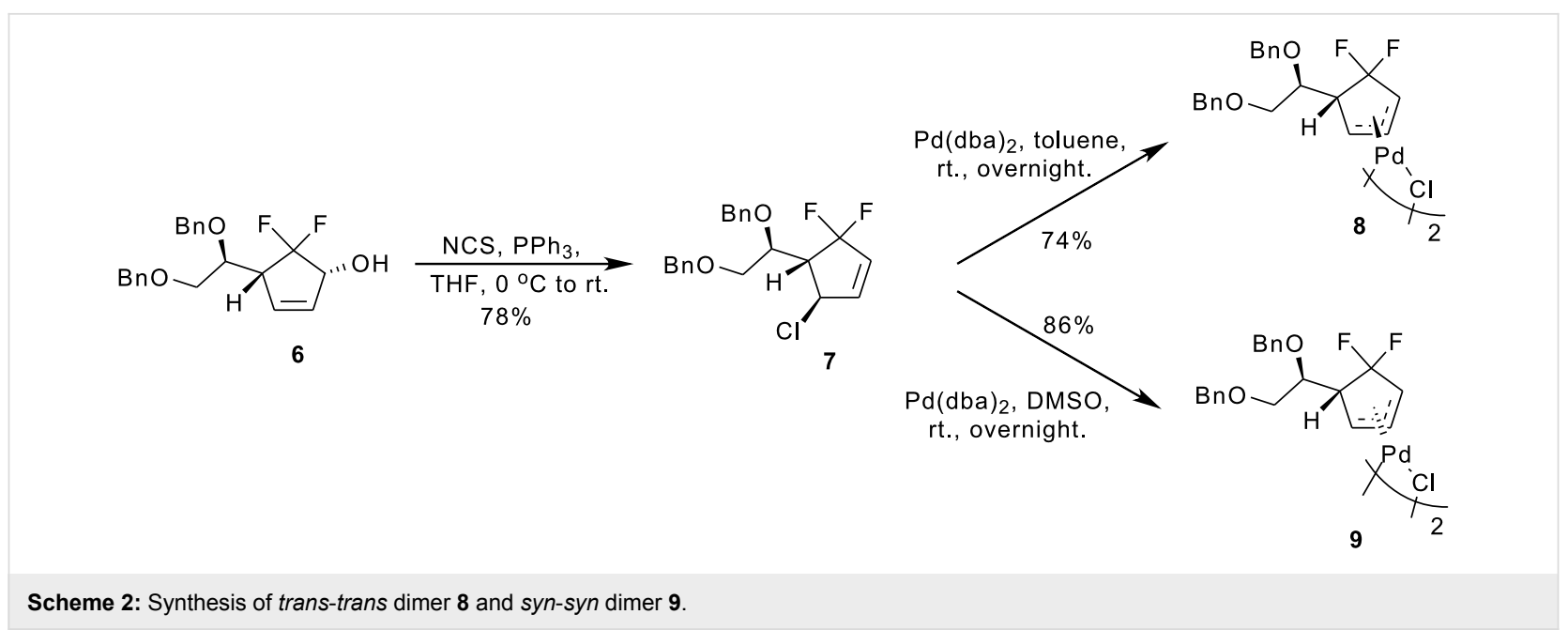

However, we only isolated the product resulting from the attack of nucleophiles from $\mathrm{C} 4$ position, which, in our opinion, was totally attributed to the strong electron-withdrawing property of neighboring gem-difluoromethylene group. ${ }^{13} \mathrm{C}$ NMR spectroscopy of the trans-trans dimer 8 unambiguously demonstrated that $\mathrm{C} 2(\mathrm{t}, \delta=73.2)$ experienced higher field than $\mathrm{C} 4(\mathrm{~s}, \delta=$ 81.4), which was also ascribed to the strong electron-withdrawing property of the $\mathrm{CF}_{2}$ group. Taking all the above

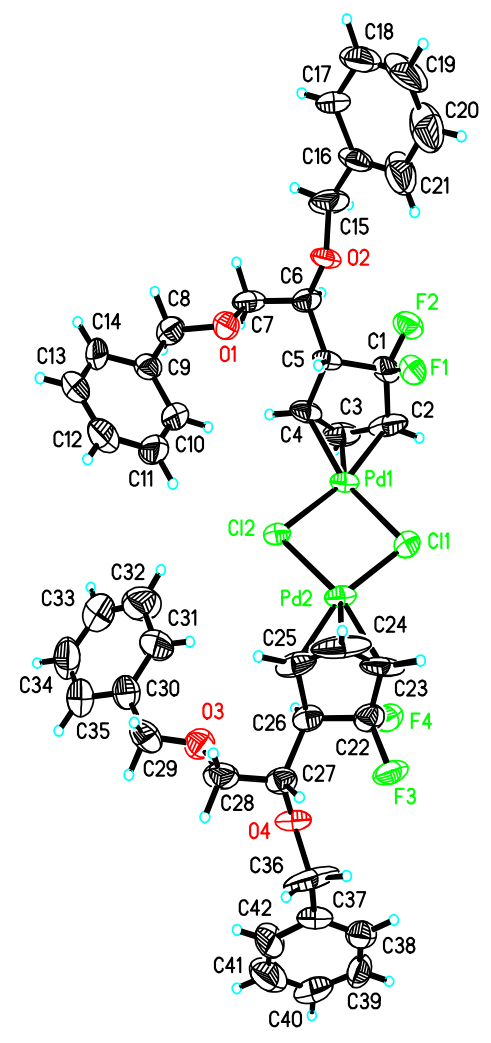

Figure 1: X-ray structure of trans-trans dimer 8. analysis together, it seems that the $\mathrm{CF}_{2}$ group's strong electronwithdrawing property leads to a higher density of positive charge at the $\mathrm{C} 4$ position of the $\pi$-allyl palladium, which predominantly promotes attack of the nucleophile on $\mathrm{C} 4$ even when the $\mathrm{C} 4$ position is more hindered than the $\mathrm{C} 2$ position.

Interestingly, we also found that treatment of the trans-trans dimer 8 with $\mathrm{PPh}_{3}$ / 3-benzoylthymine sodium at $\mathrm{rt}$ provided the nucleoside analogue 5 in $30 \%$ yield. No product was detected when $\mathrm{PPh}_{3}$ was absent (Scheme 3). Thus, we think that the reaction occurred involving the monopalladium complex $\mathbf{1 0}$. The complex $\mathbf{1 0}$ resulted from the depolymerization of the dimer 8 caused by $\mathrm{PPh}_{3}$. With this thought in mind, we attempted to isolate and characterize the monopalladium complex. Unfortunately, we found that exposure of the transtrans dimer 8 to $\mathrm{PPh}_{3} / \mathrm{AgSbF}_{6}$ afforded the monopalladium complex 11, which was too unstable to be isolated (Scheme 4). Neither did substitution of $\mathrm{PPh}_{3}$ by dppe deliver our desired complex 12 but gave instead the palladium complex 13, whose structure was confirmed by X-ray structure analysis. In our opinion, the reason we failed to isolate the monopalladium complex was also due to the presence of gem-difluoromethylene group. That is, in the absence of nucleophiles, the dimer 8 tended to lose the cyclopentanyl ligand upon treatment

\begin{tabular}{|c|c|c|c|}
\hline & bond length & bond angle & ${ }^{13} \mathrm{C}$ NMR \\
\hline Pd1-C2 & $2.105 \AA$ (11) & $\longrightarrow$ & $\longrightarrow$ \\
\hline Pd1-C4 & $2.118 \AA(9)$ & $\longrightarrow$ & $\longrightarrow$ \\
\hline Pd1-C4-C3 & - & $68.9^{\circ}(6)$ & $\longrightarrow$ \\
\hline Pd1-C2-C3 & $\longrightarrow$ & $69.2^{\circ}(7)$ & - \\
\hline $\mathrm{C} 2$ & - & $\longrightarrow$ & $73.1(\mathrm{t}, J=19.3 \mathrm{~Hz})$ \\
\hline C4 & - & - & $81.4(\mathrm{~s})$ \\
\hline
\end{tabular}




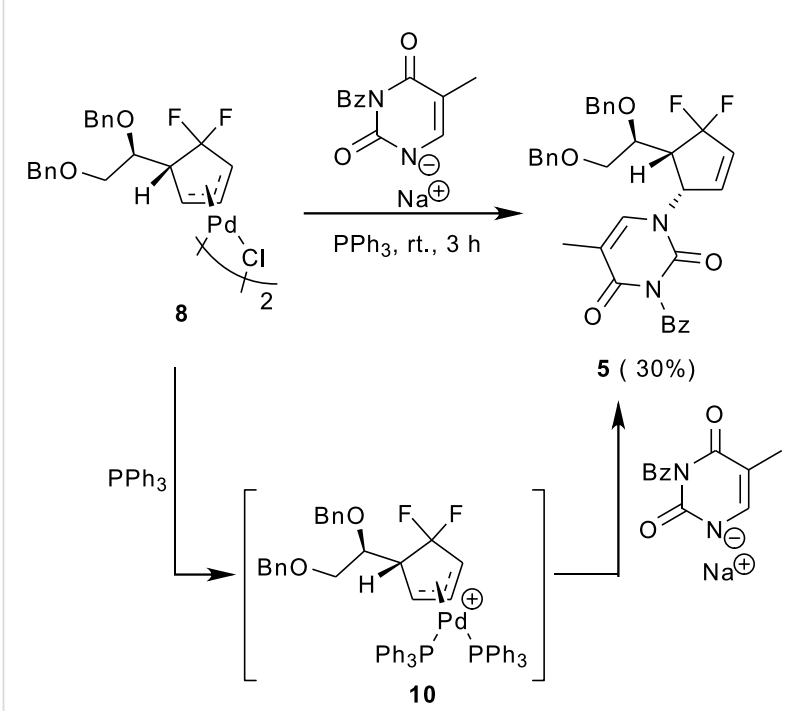

Scheme 3: Reaction of trans-trans dimer 8 with 3-benzoylthymine sodium / $\mathrm{PPh}_{3}$.

with $\mathrm{PPh}_{3}$ or dppe, because the $\mathrm{CF}_{2}$ group made the Pd- $\pi$-allyl too electron-deficient. That was why we could isolate the palladium complex $\mathbf{1 3}$ as the only product.

In conclusion, we have investigated the reaction mechanism of Pd-catalyzed allylic substitution of cyclic gem-difluorinated intermediates in detail via the crystal structure and ${ }^{13} \mathrm{C}$ NMR

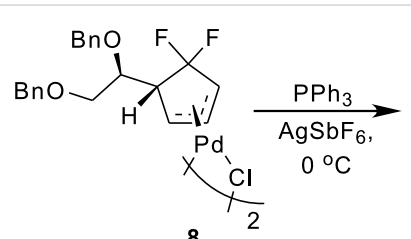
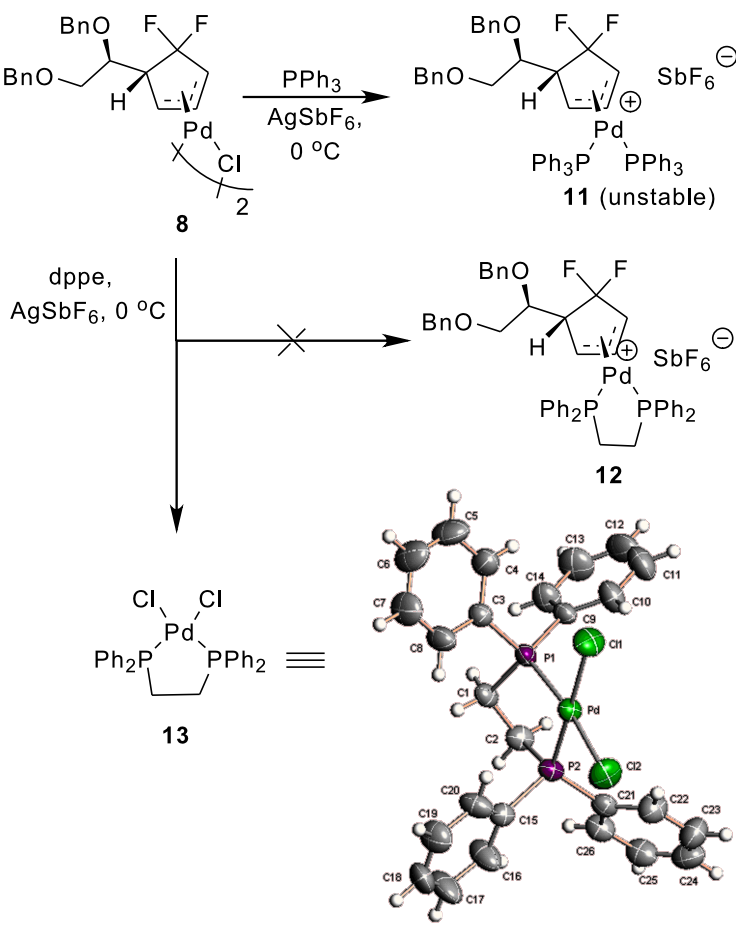

Scheme 4: Reaction of trans-trans dimer 8 with $\mathrm{PPh}_{3} / \mathrm{AgSbF}_{6}$ spectroscopy of the Pd- $\pi$-allyl complex. We found that the Pd-catalyzed reactions of cyclic gem-difluorinated allylic carbonates 1 and $\mathbf{4}$ proceeded via the symmetric $\mathrm{Pd}-\pi$-allyl bonding and highly regioselective $\gamma$-substitution resulted from the neighboring gem-difluoromethylene group. We propose that the present work opens a new avenue for the further insight into the Pd-catalyzed allylic substitution reactions.

\section{Supporting Information}

\section{Supporting Information File 1}

Experimental Section and Characterization Data of

Compounds

[http://www.beilstein-journals.org/bjoc/content/

supplementary/1860-5397-4-18-S1.doc]

\section{Acknowledgments}

The financial support of our research in this area by National Natural Science Foundation of China, the Program for Changjiang Scholars, Innovative Research Team in University and Shanghai Municipal Scientific Committee was greatly acknowledged.

\section{References}

1. Marquez, V. E. Adv. Antiviral Drug Des. 1996, 2, 89-146. doi:10.1016/S1075-8593(96)80104-3

2. Zhu, X.-F. Nucleosides, Nucleotides Nucleic Acids 2000, 19, 651-690. doi:10.1080/15257770008035015

3. Santana, L.; Teijeira, M.; Uriarte, E.; Terán, C.; Casellato, U.; Graziani, R. Nucleosides Nucleotides 1996, 15, 1179-1187. doi:10.1080/07328319608007386

4. Escuredo, V.; Ferro, B.; Santana, L.; Teijeira, M.; Uriarte, E. Nucleosides Nucleotides 1997, 16, 1453-1456. doi:10.1080/07328319708006204

5. Besada, P.; Terán, C.; Teijeira, M.; Uriarte, E. Nucleosides Nucleotides 1999, 18, 725-726. doi:10.1080/15257779908041554

6. Terán, C.; González-Moa, M. J.; Mosquera, R.; Santana, L. Nucleosides, Nucleotides Nucleic Acids 2001, 20, 999-1002. doi:10.1081/NCN-100002477

7. Santana, L.; Teijeira, M.; Terán, C.; Uriarte, E.; Viña, D. Synthesis 2001, 1532-1538. doi:10.1055/s-2001-16075

8. Besada, P.; González-Moa, M. J.; Terán, C.; Santana, L.; Uriarte, E. Synthesis 2002, 2445-2449. doi:10.1055/s-2002-35239

9. González-Moa, M. J.; Besada, P.; Teijeira, M.; Terán, C.; Uriarte, E. Synthesis 2004, 543-548. doi:10.1055/s-2004-815975

10. Estrada, E.; Uriarte, E.; Montero, A.; Teijeira, M.; Santana, L.; De Clercq, E. J. Med. Chem. 2000, 43, 1975-1985. doi:10.1021/jm991172d

11. Yang, Y.-Y.; Xu, J.; You, Z.-W.; Xu, X.-H.; Quu, X.-L.; Qing, F.-L. Org. Lett. 2007, 9, 5437-5440. doi:10.1021/ol7023955

12. Konno, T.; Ishihara, T.; Yamanaka, H. Tetrahedron Lett. 2000, 41, 8467-8472. doi:10.1016/S0040-4039(00)01485-4 
13. Konno, T.; Daitoh, T.; Ishihara, T.; Yamanaka, H. Tetrahedron: Asymmetry 2001, 12, 2743-2748. doi:10.1016/S0957-4166(01)00485-2

14. Okano, T.; Matsubara, H.; Kusukawa, T.; Fujita, M. J. Organomet. Chem. 2003, 676, 43-48. doi:10.1016/S0022-328X(03)00262-6

15. Konno, T.; Takehana, T.; Ishihara, T.; Yamanaka, H. Org. Biomol. Chem. 2004, 2, 93-98. doi:10.1039/b310950j

16. Konno, T.; Nagata, K.; Ishihara, T.; Yamanaka, H. J. Org. Chem. 2002, 67, 1768-1775. doi:10.1021/jo011013d

17. Konno, T.; Takehana, T.; Mishima, M.; Ishihara, T. J. Org. Chem. 2006, 71, 3545-3550. doi:10.1021/jo0602120

18. Nokami, J.; Matsuura, H.; Nakasima, K.; Shibata, S. Chem. Lett. 1994, 23, 1071-1074. doi:10.1246/cl.1994.1071

19. Szabó, K. J. Chem. Soc. Rev. 2001, 30, 136-143. doi:10.1039/a908934i

20. Macsári, I.; Hupe, E.; Szabó, K. J. J. Org. Chem. 1999, 64, 9547-9556. doi:10.1021/jo991172

21. Hoke, M. E.; Brescia, M.-R.; Bogaczyk, S.; DeShong, P.; King, B. W.; Crimmins, M. T. J. Org. Chem. 2002, 67, 327-335. doi:10.1021/j0010672n

22. Jonasson, C.; Kritikos, M.; Bäckvall, J.-E.; Szabó, K. J. Chem.-Eur. J. 2000, 6, 432-436. doi:10.1002/(SICI)1521-3765(20000204)6:3<432::AID-CHEM432>3.0. co;2-5

23. Kurosawa, H.; Ogoshi, S.; Kawasaki, Y.; Murai, S.; Miyoshi, M.; Ikeda, I. J. J. Am. Chem. Soc. 1990, 112, 2813-2814. doi:10.1021/ja00163a060

\section{License and Terms}

This is an Open Access article under the terms of the Creative Commons Attribution License (http://creativecommons.org/licenses/by/2.0), which permits unrestricted use, distribution, and reproduction in any medium, provided the original work is properly cited.

The license is subject to the Beilstein Journal of Organic Chemistry terms and conditions:

(http://www.beilstein-journals.org/bjoc)

The definitive version of this article is the electronic one which can be found at: $\underline{\text { doi: } 10.3762 / \text { bjoc. } 4.18}$ 